\title{
Implementasi Metode Beda Hingga Tak-Standar untuk Model Penyebaran Campak
}

\author{
Ilfa Wardatul Rizqyah*, Ari Kusumastuti, Heni Widayani \\ Program Studi Matematika, Universitas Islam Negeri Maulana Malik Ibrahim Malang, Indonesia \\ Email: ilfa.wrizqyah@gmail.com*, arikusumastuti@gmail.com, heniwidayani@mat.uin-malang.ac.id
}

\begin{abstract}
Abstrak
Model penyebaran campak merupakan salah sistem persamaan diferensial yang termasuk dalam sistem dinamik kontinu. Pada penelitian ini difokuskan untuk mengubah bentuk kontinu ke dalam bentuk diskrit dengan diskritisasi menggunakan beda hingga tak standar dan analisis kestabilan yang kemudian dilakukan simulasi numerik untuk membuktikan kestabilannya secara grafik. Berdasarkan analisis diperoleh bahwa model penyebaran campak yang diasumsikan mempunya dua titik tetap yaitu titik tetap bebas penyakit $\left(R_{0}<1\right)$ dan titik tetap endemik $\left(R_{0}>1\right)$ bersifat stabil. Kestabilan kedua titik tetap tersebut dibuktikan dengan kriteria schur-cohn dan didapat stabil dengan syarat $0<\phi(h) \leq 5$ yang memenuhi nilai $h>0$. Hasil simulasi numerik diperlihatkan bahwa model penyebaran campak terlihat konsisten secara dinamik dan menuju ke titik tetapnya. Selain itu juga simulasi numerik menunjukkan bahwa jika nilai $h$ yang semakin besar maka grafik akan semakin menuju ke titik tetap.
\end{abstract}

Kata kunci: Dinamik Diskrit; Model Penyebaran Campak; Metode Beda Hingga tak Standar; Kestabilan.

\begin{abstract}
The measles distribution model is a system of differential equations that is included in a continuous dynamic system. This research focuses on transforming the continuous form into discrete form by discretization using non-standard finite difference and stability analysis which is then carried out by numerical simulations to prove its stability graphically. Based on the analysis, it is found that the measles distribution model which is assumed to have two fixed points, namely the disease-free fixed point $\left(R_{0}<1\right)$ and the endemic fixed point $\left(R_{0}>1\right)$, is stable. The stability of the two fixed points is proven by the Schur-Cohn criteria and is obtained stable with the condition $0<\phi(h) \leq 5$ which meets the value of $h>0$. The results of the numerical simulation show that the measles distribution model is dynamically consistent and tends to the fixed point. In addition, numerical simulations show that the larger the value of $h$, the more the graph tends to the fixed point.
\end{abstract}

Keywords: discrete dynamics; measles distribution model; nonstandard finite difference method; stability.

\section{PENDAHULUAN}

Penyakit campak adalah suatu penyakit menular yang memiliki angka cukup tinggi di berbagai negara termasuk Indonesia. Oleh karena itu, beberapa penelitian berusaha untuk memecahkan permasalahan ini dengan cara memodelkan secara matematis. Salah satu peneliti yang memodelkan penyebaran campak adalah [1]. Penelitian tersebut menggunakan populasi SEIR (Suspectible, Exposed, Infected, Recovered) dan menggunakan vaksinasi sebagai strategi untuk mengontrol transmisi dinamik pada penyebarannya [1].

Metode numerik yang terkenal seperti Euler maju, Runge-Kutta orde 4 dan yang lain, terkadang tidak berhasil membangkitkan osilasi, bifurkasi, chaos, dan kesalahan titik tetap [2]. Salah satu alternatif untuk mencegah ketidakstabilan numerik adalah mengunakan metode beda hingga tak standar yang dikemukakan oleh Mickens. Penyelesaian numerik menggunakan metode beda hingga tak standar seringkali dibandingkan dengan penyelesaian menggunakan metode 
Runge-Kutta orde empat, tetapi kesimpulan yang dapat diambil adalah metode Runge-Kutta orde empat tidak bisa menjaga sifat kestabilan ketika ukuran langkah waktu berubah dan keadaan tersebut berbanding terbalik dengan skema beda hingga tak standar. [3].

Penelitian [1] membahas interaksi sosial antar populasi dengan simulasi numerik menggunakan metode Rungke-Kutta orde 4 dan Skema Beda Hingga tak Standar dengan kajian analitik pada titik tetap dan kajian basic reproductive ratio. Dalam penelitian ini mengubah sistem persamaan model kontinu ke dalam model diskrit dengan menggunakan skema beda hingga takstandar yang kemudian dianalisis pada sistem dinamik diskrit yang melibatkan titik tetap bebas penyakit dan titik tetap endemik dengan kedua keadaan basic reproductive $\left(R_{0}\right)$.

\section{Model Penyebaran Campak}

Dalam menjelaskan deskripsi model penyebaran penyakit campak yang digunakan, terlebih daluhu akan dijelaskan variabel dari diagram kompartemen sebagai berikut:

$S(t)$ : Populasi yang rentan terhadap penyakit campak

$E(t)$ : Populasi laten (muncul tanda terinfeksi penyakit)

$I(t)$ : Populasi yang terinfeksi penyakit campak

$R(t)$ : Populasi sembuh (orang pulih dan yang mendapat kekebalan vaksin)

Interpretasi model penyakit campak $S, E, I, R$ yang digambarkan oleh (Ashraf dkk, 2019) adalah sebagai berikut

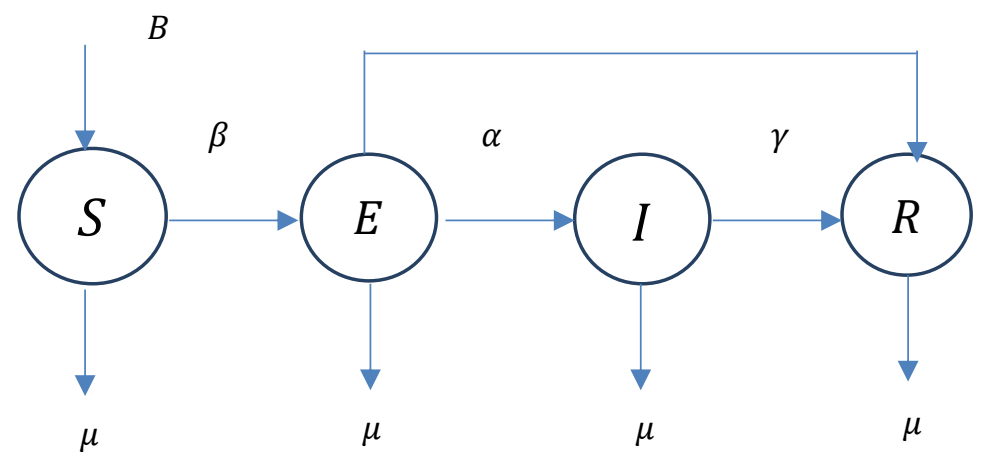

Gambar 1. Diagram Kompartemen Model Penyebaran Penyakit Campak

Dari diagram kompatemen tersebut dapat dibentuk suatu sistem persamaan model matematika penyebaran penyakit campak berikut

$$
\begin{aligned}
& \frac{d S(t)}{d t}=B-\beta S(t) I(t)-\mu S(t) \\
& \frac{d E(t)}{d t}=\beta S(t) I(t)-\mu E(t)-\alpha E(t)-\sigma E(t) \\
& \frac{d I(t)}{d t}=\alpha E(t)-\mu I(t)-\gamma I(t) \\
& \frac{d R(t)}{d t}=\gamma I(t)+\alpha E(t)-\mu R(t)
\end{aligned}
$$

Jika persamaan-persamaan dalam sistem (1.1) dijumlahkan maka diperoleh persamaan diferensial parsial total populasi

$$
\frac{d N}{d t}=B-\mu N
$$

yang memiliki solusi

$$
N(t)=\frac{1}{\mu}\left[B-\left(B-\mu N_{0}\right) e^{-\mu t}\right]
$$


di mana $N_{0}=S(0)+E(0)+I(0)+R(0)$. Persamaan (1.2) merupakan hukum konservasi (hukum populasi konstan) terkait sistem persamaan (1.1).

Momoh, dkk (2013) dalam penelitian [1] telah memberikan nilai masing-masing parameter dari model matematika penyebaran campak untuk menyelesaikan secara numerik model campak. Nilai-nilai parameter dan nilai awal variabel yang digunakan pada model tersebut diberikan pada tabel berikut ini

Tabel 1 Nilai Awal Model Penyebaran Penyakit Campak [4]

\begin{tabular}{clc}
\hline Parameter & \multicolumn{1}{c}{ Keterangan } & Nilai \\
\hline$S(0)$ & Nilai awal untuk populasi Suspectible & 0.6 orang \\
$E(0)$ & Nilai awal untuk populasi Exposed & 0.25 orang \\
$I(0)$ & Nilai awal untuk populasi Infected & 0.1 orang \\
$R(0)$ & Nilai awal untuk populasi Recovered & 0.05 orang \\
\hline
\end{tabular}

Tabel 2 Nilai Parameter Penyebaran Penyakit Campak [4]

\begin{tabular}{clc}
\hline Parameter & \multicolumn{1}{c}{ Keterangan } & Nilai \\
\hline$\mu$ & Laju kematian alami & 0,2 perhari \\
$\sigma$ & Laju kesembuhan populasi $E$ karena pengaruh vaksin & 0,25 perhari \\
$\gamma$ & Laju kesembuhan populasi $I$ & 0.2 perhari \\
$B$ & Laju kelahiran populasi $S$ & 0.32 perhari \\
$\alpha$ & Laju populasi laten $E$ menjadi populasi terinfeksi $I$ & 0.01 perhari \\
\hline
\end{tabular}

\section{Bilangan Reproduksi Dasar}

Banyaknya individu rentan yang terinfeksi secara langsung oleh individu lain yang telah terinfeksi, dan masuk ke dalam populasi yang seluruhnya masih rentan disebut bilangan reproduksi dasar [5]. Berdasarkan perhitungan tersebut, bilangan reproduksi dasar dari sistem persamaan (2.1) adalah:

$$
R_{0}=\frac{B \alpha \beta}{\mu(\mu+\alpha+\sigma)(\mu+\gamma)} .
$$

\section{Titik Tetap}

1. Titik Tetap Bebas Penyakit

Titik tetap bebas penyakit artinya dalam populasi tersebut tidak terjadi penyebaran penyakit menular atau belum ada individu yang terinfeksi pada saat $t$ sehingga $(I(t)=0)$. Titik tetap bebas penyakit dari sistem persamaan (1.1) diperoleh $T_{0}^{*}(S, E, I, R)=\left(\frac{B}{\mu}, 0,0,0\right)$.

2. Titik Tetap Endemik

Suatu ekuilibrium endemik artinya suatu kondisi di mana terjadi penularan penyakit dengan asumsi terdapat individu terinfeksi penyakit atau $I(t) \neq 0$. Dengan demikian diperoleh titik ekuilibrium endemik $T_{e}^{*}(S, E, I, R)=\left(\frac{B}{\mu\left(R_{0}-1\right)+\mu}, \frac{(\mu+\gamma) \mu\left(R_{0}-1\right)}{\alpha \beta}, \frac{\mu}{\beta}\left(R_{0}-\right.\right.$ 1), $\left.\frac{(\mu+2 \gamma) \mu\left(R_{0}-1\right)}{\beta \mu}\right)$. 


\section{Kriteria Kestabilan Titik Tetap}

Kestabilan titik tetap dapat ditentukan dengan menganalisis sistem hasil linearisasi. Untuk suatu persamaan beda dengan orde $k$ berikut

$$
x(n+k)+p_{1} x(n+k-1)+\cdots+p_{k} x(n)=0,
$$

di mana $p_{i}$ bernilai konstan $\forall i=1,2, \ldots, k$ dan $p_{k} \neq 0$, persamaan karakteristik untuk persamaan (1.4) adalah

$$
P(\lambda)=\lambda^{k}+p_{1} \lambda^{k-1}+\cdots+p_{k}
$$

Misalkan $\lambda_{i}$ merupakan akar-akar karakteristik persamaan (1.5), maka berlaku semua solusi dari persamaan (1.5) konvergen menuju 0 (stabil asimtotik) jika dan hanya jika $\left|\lambda_{i}\right|<1$ [5].

Berdasarkan kriteria kestabilan Schur-Cohn, solusi dari persamaan karakteristik (1.5) dikatakan stabil asimtotik jika memenuhi syarat-syarat berikut

(i). $P(1)>0$,

(ii). $(-1)^{k} P(-1)>0$,

(iii). Matriks $(k-1) \times(k-1)$ merupakan positif innerwise

$$
B^{ \pm}{ }_{k-1}=\left(\begin{array}{ccccc}
1 & 0 & \cdots & & 0 \\
p_{1} & 1 & & & 0 \\
\vdots & & & & \vdots \\
p_{k-3} & & & & \\
p_{k-2} & p_{k-3} & \cdots & p_{1} & 1
\end{array}\right) \pm\left(\begin{array}{ccccc}
0 & 0 & \cdots & 0 & p_{k} \\
0 & 1 & & & p_{k-1} \\
\vdots & \vdots & & & \vdots \\
0 & p_{k} & & & p_{3} \\
p_{k} & p_{k-1} & \cdots & p_{3} & p_{2}
\end{array}\right)
$$

Matriks $B$ dikatakan positif innerwise jika sub determinan di dalam matriks tersebut bernilai positif [5].

\section{Metode Beda Hingga tak Standar}

Mickens (1999) menjabarkan metode beda hingga tak standar dalam bentuk skema eksak yang kemudian dikembangkan kembali menjadi skema beda hingga tak standar. Skema beda hingga eksak didefinisikan sebagai salah satu skema yang memiliki solusi yang tepat sama dengan solusi persamaan diferensialnya. Dalam persamaan diferensial berikut ini, misalkan

$$
\frac{d u}{d t}=-\lambda u, u(0)=u_{0}
$$

persamaan (1.4) memiliki bentuk solusi sebagai berikut

$$
u(t)=u_{0} e^{-\lambda t}
$$

Berdasarkan [7] skema eksak dari persamaan diterensial biasa linier orde $N$ dapat dibentuk dengan matriks determinan berikut

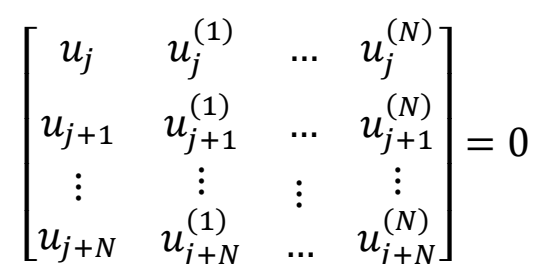

dengan $u_{j}^{(i)}, i=1,2, \ldots, N$ merupakan fungsi bebas linier dari fungsi $u_{j}^{(i)}=u^{(i)}\left(t_{j}\right)$.

Skema eksak dari persamaan (1.4) dapat dikonstruksi dengan menggunakan persamaan (1.6) sebagai berikut

$$
\left[\begin{array}{cc}
u_{j} & e^{-\lambda t_{j}} \\
u_{j+1} & e^{-\lambda t_{j+1}}
\end{array}\right]=e^{-\lambda t_{j}}\left[\begin{array}{cc}
u_{j} & 1 \\
u_{j+1} & e^{-\lambda t}
\end{array}\right]
$$


sehingga didapat skema eksak untuk persamaan (1.7) yaitu

$$
u_{j+1}=e^{-\lambda t} u_{j}
$$

Jika kedua sisi pada persamaan (2.33) dikurangkan dengan $u_{j}$, maka diperoleh persamaan berikut

dengan menyederl

$$
u_{j+1}-u_{j}=\left(e^{-\lambda t}-1\right) u_{j}=-\lambda\left(\frac{1-e^{-\lambda t}}{\lambda}\right) u_{j}
$$

persamaan (1.4) adalah

$$
\frac{u_{j+1}-u_{j}}{\left(\frac{1-e^{-\lambda t}}{\lambda}\right)}=-\lambda u_{j}
$$

Pada persamaan (1.4), jika didiskritisasi menggunakan beda maju maka diperoleh

$$
\frac{d u}{d t} \rightarrow \frac{u_{j+1}-u_{j}}{h}
$$

namun untuk turunan diskrit pertama persamaan (2.29) diberikan

$$
\frac{d u}{d t} \rightarrow \frac{u_{j+1}-u_{j}}{\phi}
$$

dengan $\phi$ adalah fungsi denominator sebagaı berıkut

$$
\phi=\left(\frac{1-e^{-\lambda t}}{\lambda}\right)
$$

Pendekatan beda hingga pada persamaan (1.y) merupakan pengembangan dari pendekatan beda maju dan beda pusat untuk persamaan (1.4). Dalam hal ini ukuran langkah $\Delta t$ diganti dengan fungsi denominator $\phi$. Suatu skema dikatakan sebagai skema beda hingga tak standar, jika skema tersebut memenuhi syarat tersebut [8].

\section{METODE PENELITIAN}

Terdapat tiga metode penelitian dalam menyelesaikan ketiga rumusan masalah dalam penelitian ini dan mengikuti langkah-langkah sebagai berikut:

2.1. Diskritisasi Model dengan Skema Beda Hingga Tak Standar

Subbab ini menjelaskan perubahan bentuk model penyebaran campak kontinu dari jurnal

[1] ke dalam bentuk diskrit menggunakan skema beda hingga tak standar.

2.2. Analisis Kestabilan dari Titik Tetap Model

Subbab ini berisi analisis dinamik dari model penyebaran penyakit campak yaitu:

1. Menentukan titik tetap pada model penyebaran penyakit campak.

2. Melakukan linierisasi model penyebaran penyakit campak diskrit menggunakan matriks Jacobi.

3. Menganalisis kestabilan dari titik tetap model penyebaran penyakit campak diskrit menggunakan kriteria kestabilan Schur-Cohn.

2.3. Penyelesaian Solusi Numerik dan Interpretasinya pada Model Penyebaran Campak dengan Skema Beda Hingga tak Standar.

Subbab ini akan membahas mengenai simulasi numerik dari model penyebaran penyakit campak yang telah didiskritasi dengan skema beda hingga tak standar untuk dua kondisi yaitu kondisi bebas penyakit atau $R_{0}<1$ dan kondisi endemik atau $R_{0}>1$. 


\section{HASIL DAN PEMBAHASAN}

Sistem persamaan (1.1) didiskritisasi menggunakan metode beda hingga tak standar dengan menggunakan fungsi penyebut $\phi(h)$.Fungsi penyebut tersebut digunakan agar total populasi eksak tetap terjaga, yaitu dengan cara mendiskrititasi persamaan (1.2) dan didapat persamaan berikut:

$$
\frac{d N}{d t}=\frac{N^{n+1}-N^{n}}{\phi(h)}=B-\mu N^{n}
$$

persamaan di atas merupakan bentuk diskritisasi tak standar dari persamaan konservasi populasi (1.3) sehingga fungsi penyebut $\phi(h)$ dapat diperoleh dengan membandingkan solusi persamaan (1.5) yaitu solusi pada persamaan (1.6) pada saat $t=t^{n+1}$ yaitu $N^{n+1}=$ $\frac{1}{\mu}\left[B-\left(B-\mu N^{n}\right) e^{-\mu h}\right]$. Dengan cara ini diperoleh bahwa fungsi penyebut harus memenuhi

$$
\phi(h)=\frac{1-e^{-\mu h}}{\mu} .
$$

Oleh karena itu, proses diskritisasi menggunakan skema beda hingga tak standar pada model penyebaran campak dapat dipaparkan sebagai berikut:

$$
\begin{aligned}
& \frac{S^{n+1}-S^{n}}{\phi(h)}=B-\beta S^{n+1} I^{n}-\mu S^{n+1} \\
& \frac{E^{n+1}-E^{n}}{\phi(h)}=\beta S^{n+1} I^{n}-(\mu+\alpha++\sigma) E^{n+1} \\
& \frac{I^{n+1}-I^{n}}{\phi(h)}=\alpha E^{n+1}-(\mu+\gamma) I^{n+1} \\
& \frac{R^{n+1}-R^{n}}{\phi(h)}=\gamma I^{n+1}+\alpha E^{n+1}-\mu R^{n+1} .
\end{aligned}
$$

Dari persamaan (1.15) diperoleh bentuk persamaan eksplisit sebagai berikut

$$
\begin{aligned}
S^{n+1} & =\frac{B h+S^{n}}{\left(1+\beta \phi(h) I^{n}+\mu \phi(h)\right)} \\
E^{n+1} & =\frac{\phi(h) \beta S^{n+1} I^{n}+E^{n}}{1+\phi(h)(\mu+\alpha++\sigma)} \\
I^{n+1} & =\frac{\phi(h) \alpha E^{n+1}+I^{n}}{1+\phi(h)(\mu+\gamma)} \\
R^{n+1} & =\frac{\phi(h) \gamma I^{n+1}+\phi(h) \alpha E^{n+1}+R^{n}}{1+\phi(h) \mu}
\end{aligned}
$$

Diskritisasi persamaan (3.4) menggunakan skema beda hingga tak standar kemudian digunakan untuk menganalisa konvergensi dari model SEIR penyebaran campak. Matriks Jacobi dari sistem persamaan (3.4) secara umum sebelum dievaluasi di titik kesetimbangan berbentuk sebagai berikut 


$$
J=\left(\begin{array}{cccc}
\frac{\partial S^{n+1}}{\partial S^{n}} & \frac{\partial S^{n+1}}{\partial E^{n}} & \frac{\partial S^{n+1}}{\partial I^{n}} & \frac{\partial S^{n+1}}{\partial R^{n}} \\
\frac{\partial E^{n+1}}{\partial S^{n}} & \frac{\partial E^{n+1}}{\partial E^{n}} & \frac{\partial E^{n+1}}{\partial I^{n}} & \frac{\partial E^{n+1}}{\partial R^{n}} \\
\frac{\partial I^{n+1}}{\partial S^{n}} & \frac{\partial I^{n+1}}{\partial E^{n}} & \frac{\partial I^{n+1}}{\partial I^{n}} & \frac{\partial I^{n+1}}{\partial R^{n}} \\
\frac{\partial R^{n+1}}{\partial S^{n}} & \frac{\partial R^{n+1}}{\partial E^{n}} & \frac{\partial R^{n+1}}{\partial I^{n}} & \frac{\partial R^{n+1}}{\partial R^{n}}
\end{array}\right)
$$

Dengan memisalkan

$$
\begin{aligned}
& a=\phi(h)(\beta I+\mu)+1 \\
& b=1+\phi(h)(\mu+\alpha+\sigma) \\
& c=1+\phi(h)(\mu+\sigma) \\
& d=\mu \phi(h)+1 \\
& e=B \phi(h)+S^{*} \\
& j=1+\phi(h)(\gamma+\mu+\sigma) \\
& k=\frac{p l^{2} e}{a^{2} b} \\
& l=\phi(h) \beta \\
& m=\phi(h) \gamma \\
& p=\phi(h) \alpha \\
& q=p \alpha(m+j) \\
& W=\frac{l(k+1)-k c}{c d}
\end{aligned}
$$

Didapat matriks Jacobi sebagai berikut

$$
J=\left(\begin{array}{cccc}
\frac{1}{a} & 0 & -\frac{e l}{a^{2}} & 0 \\
\frac{l}{a b} & \frac{1}{b} & -\frac{l^{2} e}{a^{2} b} & 0 \\
\frac{p l}{a b c} & \frac{p}{b c} & -\frac{k}{c} & 0 \\
\frac{q l}{a b c d} & \frac{q}{b c d} & W & \frac{1}{d}
\end{array}\right)
$$

\subsection{Kestabilan Titik Tetap Bebas Penyakit}

Persamaan karakteristik dari matriks Jacobi (3.6) tersebut berupa polinom berderajat empat yaitu

$$
P(\lambda)=\lambda^{4}+A_{1} \lambda^{3}+A_{2} \lambda^{2}+A_{3} \lambda+A_{4}
$$

dengan 


$$
\begin{aligned}
& A_{1}=\left(\frac{k}{c}-\frac{1}{d}-\frac{1}{b}-\frac{1}{a}\right) \\
& A_{2}=-\frac{k}{c d}-\frac{k}{b c}-\frac{k}{a c}+\frac{e l^{2} p}{a^{2} b^{2} c}+\frac{e l^{2} p}{a^{3} b c}+\frac{1}{b d}+\frac{1}{a d}+\frac{1}{a b} \\
& A_{3}=\frac{k}{b c d}+2 \frac{k}{a c d}-\frac{e l^{2} p}{a^{2} b^{2} c d}-\frac{e l^{2} p}{a^{2} b c d}-\frac{3 e l^{2} p}{a^{3} b^{2} c}-\frac{1}{a b d} \\
& A_{4}=\frac{3 e l^{2} p}{a^{3} b^{2} c d}-\frac{k}{a b c d}
\end{aligned}
$$

Titik tetap bebas penyakit $T_{0}^{*}=\left(\frac{B}{\mu}, 0,0,0\right)$ disubstitusikan ke persamaan karakteristik (3.7) sedemikian hingga menghasilkan nilai koefisien yang digunakan pada kasus khusus dengan nilai parameter pada Tabel 1 dan Tabel 2. Nilai parameter tersebut akan disubstitusikan ke dalam kriteria kestabilan Schur-Cohn untuk melihat sifat kestabilan titik $T_{0}^{*}$ secara khusus. Bentuk koefisien $A_{1}, A_{2}, A_{3}$, dan $A_{4}$. Fungsi $\phi(h)$ berada pada interval $0 \leq$ $\phi(h) \leq \frac{1}{\mu}=\frac{1}{0.2}=5$.

Lebih lanjut, digunakan nilai batas atas dari $\phi(h)$ yakni sebesar 5 untuk membuktikan kestabilan titik tetap bebas penyakit $T_{0}^{*}$. Nilai dari $A_{1}, A_{2}, A_{3}$, dan $A_{4}$ dapat diperoleh sebagaimana tabel berikut.

\begin{tabular}{cc} 
Tabel 3 Nilai Koefisien & $A_{1}, A_{2}, A_{3}$, dan $A_{4}$ \\
\hline Koefisien & Nilai \\
\hline$A_{1}$ & -0.9021 \\
$A_{2}$ & 0.4332 \\
$A_{3}$ & -0.3301 \\
$A_{4}$ & 0.0755 \\
\hline
\end{tabular}

Dari Tabel 3 tersebut dapat dianalisis kestabilan secara khusus melalui kriteria kestabilan Schur-Cohn berikut:

1. $P(1)=0.2765>0$

2. $(-1)^{k} P(-1)=2.741>0$

3. $B_{3}{ }^{ \pm}=\left[\begin{array}{ccc}1 & 0 & 0 \\ A_{1} & 1 & 0 \\ A_{2} & A_{1} & 1\end{array}\right] \pm\left[\begin{array}{ccc}0 & 0 & A_{4} \\ 0 & A_{4} & A_{3} \\ A_{4} & A_{3} & A_{2}\end{array}\right]$

a. $\quad B_{3}{ }^{+}=\left[\begin{array}{ccc}1 & 0 & 0 \\ A_{1} & 1 & 0 \\ A_{2} & A_{1} & 1\end{array}\right]+\left[\begin{array}{ccc}0 & 0 & A_{4} \\ 0 & A_{4} & A_{3} \\ A_{4} & A_{3} & A_{2}\end{array}\right]$

$$
=1.1773>0
$$

b. $\quad B_{3}{ }^{-}=\left[\begin{array}{ccc}1 & 0 & 0 \\ A_{1} & 1 & 0 \\ A_{2} & A_{1} & 1\end{array}\right]-\left[\begin{array}{ccc}0 & 0 & A_{4} \\ 0 & A_{4} & A_{3} \\ A_{4} & A_{3} & A_{2}\end{array}\right]$

$$
=0.6987>0
$$


Dari ketiga syarat di atas didapat bahwa sistem persamaan model penyebaran penyakit campak pada titik tetap bebas penyakit stabil asimtotik dengan syarat $\phi(h)>0$.

\subsection{Kestabilan Titik Tetap Endemik}

Untuk kasus endemik, persamaan karakteristik dari matriks Jacobi (3.12) tersebut berupa polinom berderajat empat yaitu

$$
P(\lambda)=\lambda^{4}+D_{1} \lambda^{3}+D_{2} \lambda^{2}+D_{3} \lambda+D_{4}
$$

dengan

$$
\begin{aligned}
& D_{1}=\left(\frac{k}{c}-\frac{1}{d}-\frac{1}{b}-\frac{1}{a}\right) \\
& D_{2}=-\frac{k}{c d}-\frac{k}{b c}-\frac{k}{a c}+\frac{e l^{2} p}{a^{2} b^{2} c}+\frac{e l^{2} p}{a^{3} b c}+\frac{1}{b d}+\frac{1}{a d}+\frac{1}{a b} \\
& D_{3}=\frac{k}{b c d}+2 \frac{k}{a c d}-\frac{e l^{2} p}{a^{2} b^{2} c d}-\frac{e l^{2} p}{a^{2} b c d}-\frac{3 e l^{2} p}{a^{3} b^{2} c}-\frac{1}{a b d} \\
& D_{4}=\frac{3 e l^{2} p}{a^{3} b^{2} c d}-\frac{k}{a b c d}
\end{aligned}
$$

Titik tetap endemik

$$
T_{e}^{*}=\left(\frac{B}{\mu\left(R_{0}-1\right)+\mu}, \frac{(\mu+\gamma) \mu\left(R_{0}-1\right)}{\alpha \beta}, \frac{\mu}{\beta}\left(R_{0}-1\right), \frac{(\mu+2 \gamma) \mu\left(R_{0}-1\right)}{\beta \mu}\right)
$$

disubstitusikan ke persamaan karakteristik (3.8). Sama halnya dengan titik tetap bebas penyakit, digunakan nilai batas atas dari $\phi(h)$ yakni sebesar 5 untuk membuktikan kestabilan titik tetap endemik $T_{e}^{*}$. Nilai dari $D_{1}, D_{2}, D_{3}$, dan $D_{4}$ dapat diperoleh

Tabel 4 Nilai Koefisien $D_{1}, D_{2}, D_{3}$, dan $D_{4}$

\begin{tabular}{cc}
\hline Koefisien & Nilai \\
\hline$D_{1}$ & -0.4955 \\
$D_{2}$ & -0.0955 \\
$D_{3}$ & 0.0466 \\
$D_{4}$ & -6.3050 \\
\hline
\end{tabular}

Dari Tabel 3 tersebut dapat dianalisis kestabilan secara khusus melalui kriteria kestabilan Schur-Cohn berikut:

1. $P(1)=0.456>0$

2. $(-1)^{k} P(-1)=1.353>0$

3. $B_{3}{ }^{ \pm}=\left[\begin{array}{ccc}1 & 0 & 0 \\ A_{1} & 1 & 0 \\ A_{2} & A_{1} & 1\end{array}\right] \pm\left[\begin{array}{ccc}0 & 0 & A_{4} \\ 0 & A_{4} & A_{3} \\ A_{4} & A_{3} & A_{2}\end{array}\right]$

a. $\quad B_{3}{ }^{+}=\left[\begin{array}{ccc}1 & 0 & 0 \\ A_{1} & 1 & 0 \\ A_{2} & A_{1} & 1\end{array}\right]+\left[\begin{array}{ccc}0 & 0 & A_{4} \\ 0 & A_{4} & A_{3} \\ A_{4} & A_{3} & A_{2}\end{array}\right]$ 


$$
=0.9524>0
$$

b. $\quad B_{3}{ }^{-}=\left[\begin{array}{ccc}1 & 0 & 0 \\ A_{1} & 1 & 0 \\ A_{2} & A_{1} & 1\end{array}\right]-\left[\begin{array}{ccc}0 & 0 & A_{4} \\ 0 & A_{4} & A_{3} \\ A_{4} & A_{3} & A_{2}\end{array}\right]$

$$
=1.070>0
$$

Dari ketiga syarat di atas didapat bahwa sistem persamaan model penyebaran penyakit campak pada titik tetap endemik stabil asimtotik dengan syarat $\phi(h)>0$.

Dalam simulasi numerik yang menggunakan bantuan sofware Matlab, nilai awal mengacu pada tabel 1 dan nilai parameter mengacu pada tabel.2 dengan $\phi(h)=\frac{1-e^{-\mu h}}{\mu}$. Grafik dapat disajikan dalam bentuk berikut

\section{A. Kasus Titik Tetap Bebas Penyakit}

Pada simulasi dengan $R_{0}<1$ diperoleh ketika digunakan laju interaksi $\beta=1$. Grafik $S(t), E(t), I(t)$ dan $R(t)$ untuk $h=0.01$ dan $h=1$ dengan formula $\phi(h)=\frac{1-e^{-\mu h}}{\mu}$ adalah sebagai berikut.

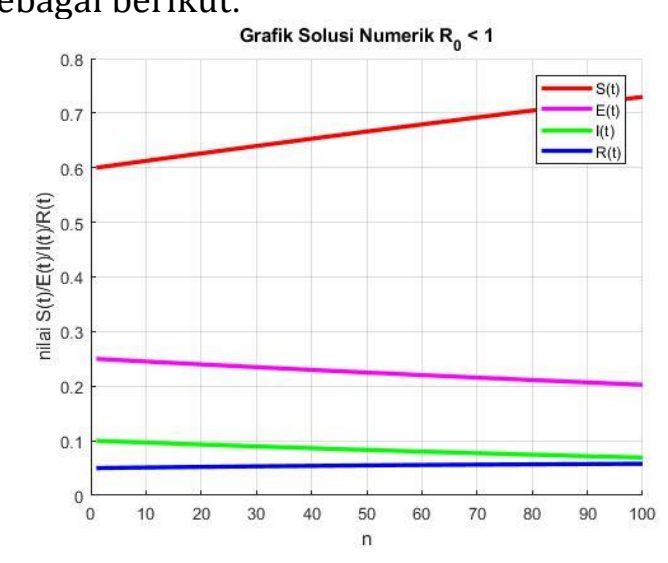

Gambar 2 Solusi Numerik $\boldsymbol{S}(\boldsymbol{t}), \boldsymbol{E}(\boldsymbol{t}), \boldsymbol{I}(\boldsymbol{t})$ dan $\boldsymbol{R}(\boldsymbol{t})$ untuk $\boldsymbol{h}=\mathbf{0 . 0 1}$

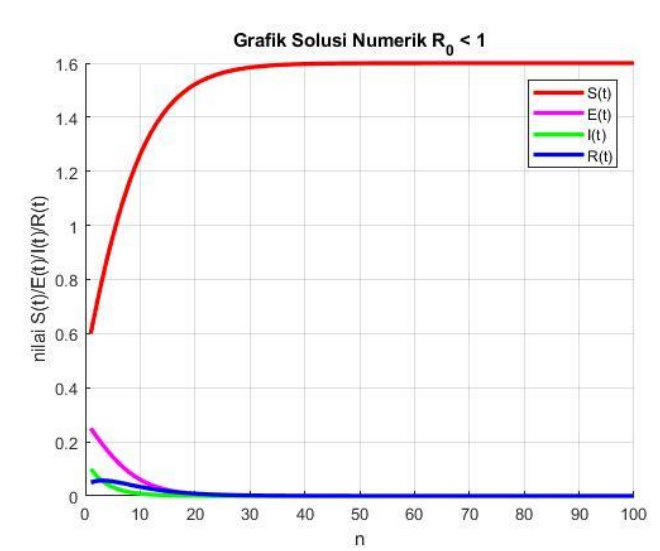

Gambar 3 Solusi Numerik $\boldsymbol{S}(\boldsymbol{t}), \boldsymbol{E}(\boldsymbol{t}), \boldsymbol{I}(\boldsymbol{t})$ dan $\boldsymbol{R}(\boldsymbol{t})$ untuk $\boldsymbol{h}=\mathbf{0 . 0 1}$

Gambar 2 dan Gambar 3 menunjukkan bahwa solusi dengan ukuran langkah $\phi(0.01)=$ $\frac{1-e^{-\mu(0.01)}}{0.2}$ lebih lambat menuju kondisi kesetimbangan dibandingkan solusi dengan ukuran langkah $\phi(1)=\frac{1-e^{-\mu(1)}}{0.2}$. Namun simulasi numerik menggunakan metode beda hingga tak standar menunjukkan konvergensi ke titik kesetimbangan 


\section{B. Kasus Titik Tetap Endemik}

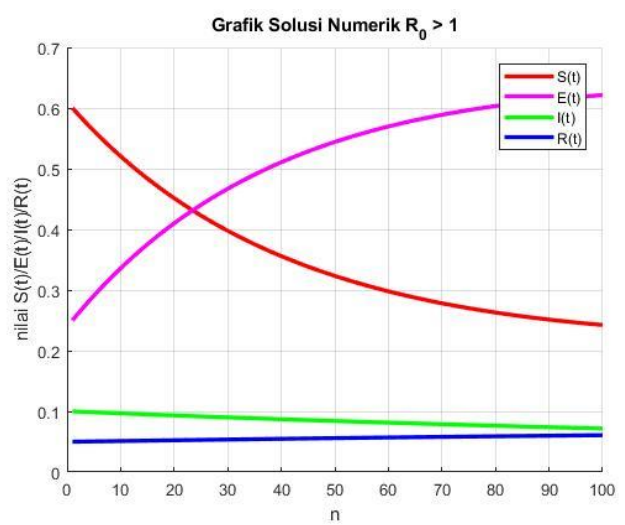

Gambar 4 Solusi Numerik $S(t), E(t), I(t)$ dan $R(t)$ untuk $h=0.01$

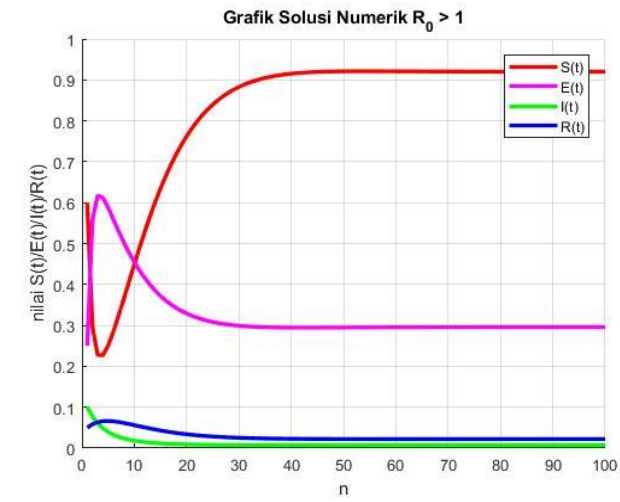

Gambar 5 Solusi Numerik $S(t), E(t), I(t)$ dan $R(t)$ untuk $h=0.01$

Gambar 4 dan Gambar 5 menunjukkan bahwa solusi dengan ukuran langkah $\phi(0.01)=$ $\frac{1-e^{-\mu(0.01)}}{0.2}$ lebih lambat menuju kondisi kesetimbangan dibandingkan solusi dengan ukuran langkah $(\phi 1)=\frac{1-e^{-\mu(1)}}{0.2}$. Namun simulasi numerik menggunakan metode beda hingga tak standar menunjukkan konvergensi ke titik kesetimbangan dengan nilai $\beta$ yang cukup besar yaitu $\beta=20$ untuk menghasilkan $R_{0}>1$.

\section{KESIMPULAN}

Berdasarkan pemaparan di atas, dapat disimpulkan bahwa hasil analisis kestabilan menggunakan kriteria Schur-Cohn menunjukkan bahwa model beda hingga tak standar penyebaran penyakit campak stabil secara numerik untuk dua kondisi yaitu kondisi bebas penyakit dan endemik dengan $0 \leq \phi(h) \leq \frac{1}{\mu}$ untuk $h \geq 0$. Hasil simulasi numerik untuk model beda hingga tak standar penyebaran penyakit campak dengan ukuran langkah $\phi(h)=\frac{1-e^{-\mu h}}{\mu}$ menunjukkan bahwa semakin besar nilai $h$ yang digunakan maka grafik akan cepat konvergen menuju titik tetapnya.

\section{DAFTAR PUSTAKA}

[1] Farah, Ashraf dkk. (2019). Nonstandard Finite Difference Scheme for Control of Measles Epidemiology. Departemen of Mathematics and Statistics, University of Lahore, Pakistan.

[2] Lapidus, L,. Dan G. F. Pinder. (1999). Nemurical Solution of Partial Differential Equation in Science abd Engineering. John Wiley \& Sons, Inc. New York.

[3] Nugroho, Sapto. (2018). Analisis Dinamik Model SIR dengan Skema Beda Hingga Tak Standar. Universitas Jendral Soedirman.

[4] Momoh AA. 2013. Mathematical model for control of measles epidemiology. Jurnal Internasional Matematika Murni dan Terapan. 87(5) : 707-717.

[5] Giessecke, J. 2002. Modern Infectious Disease Epidemiology, $2^{\text {nd }}$ edition. Florida: CRC Press.

[6] Elaydi, S. 2005. An Introduction to Difference Equations. Third edition. Springer. United State of America.

[7] Mickens, R,. E. (1999). Advances in the Application of Nonstandard Finite Difference Schemes. World Scientific Publishing Co. Pte, Ltd. Singapore. 